HERMES 148, 2020/3, 259-277

DOI 10.25162/HERMES-2020-0019

BERNARDO BALLESTEROS

\title{
Poseidon and Zeus in Iliad 7 and Odyssey 13: on a case of Homeric imitation*
}

\begin{abstract}
This article aims to contribute to the current debate on how imitation in early Greek epic can be identified and assessed. Two divine scenes in Iliad Book 7 and Odyssey Book 13 are compared in the light of their traditional background and contextual significance. It is suggested that there are grounds to interpret this as a case of imitation on the Odyssey poet's part which, however, was not necessarily meant to elicit recognition of the subtext. A methodological point is made by showing that it is possible to argue for a specific intertextual relation by considering the traditional techniques involved.

Keywords: Homer - Iliad - Odyssey - Intertextuality - Gods
\end{abstract}

\section{Introduction: Intertextuality and early Greek epic}

The present article aims to contribute to the current debate on how imitation in early Greek epic can be identified and assessed, by looking at two related divine scenes, featuring Zeus and Poseidon, in Iliad 7 and Odyssey 13. We begin with a discussion of the current state of scholarship on intertextual interaction in early Greek epic. This discussion should help us clarify and contextualise the objectives of the comparison addressed thereafter, namely to better assess the possibilities of intertextuality between the two extant heroic poems by fully considering their oral-traditional background, and to explore how audience expectations shaped such possibilities. ${ }^{1}$

A long tradition of modern studies has debated the relationship between the Iliad and the Odyssey. ${ }^{2}$ Well into the twentieth century, most of these works set out to demonstrate the priority of the Iliad, and to observe the Odyssey's conscious use of its predeces-

* Aspects of the present argument were presented in 2016 to audiences in Oxford and Nijmegen, whom I wish to thank. I am also grateful to B. Currie, M. Hose, A. Kelly and A. Lardinois, who commented on written versions, though I remain responsible for the article's contents and shortcomings.

1 Throughout this contribution the words 'intertextual' and 'intertextuality' are used in the 'soft sense', as facetiously defined by G. DANEK (2010) 129: 'a newly coined label for old fashioned concepts like 'citation' or 'allusion"' (viz. between distinct works or postulated mythic and song-traditions), and including artistic redeployment. Cf. J. BURGESS (2006) 162 n. 32, with literature. 
sor: signs of interaction were found in the common phraseology, motifs and narrative movements. But the oralist theory and its precursors demonstrated that precisely such shared elements were the signs of the traditional nature of early Greek epic. Recurring formulae and themes (or 'type-scenes') are, in this view, the common property of the traditionally-trained singers, and should never, therefore, be considered indicators of direct reception, imitation, or emulation. ${ }^{3}$ Yet dialogues between oralism and neoanalysis over the last three decades have renewed interest into intertextual possibilities in early Greek epic, by confronting the question of whether and how they can be assessed through the lens of oral (or orally-derived, in J. M. FOLEY's terms) compositional techniques. ${ }^{4}$

'Neoanalytical' enquiries seek to uncover Homer's engagement with a broader tradition of heroic song, as exemplified by the Epic Cycle and hypothetical predecessors. Such predecessors are assumed to have had sufficient degrees of fixity when Homer composed, at least on the level of a coherent plot. Interaction should be seen in the re-elaboration or creative insertion of episodes or motifs originally present in, or associated with, the postulated pre-existing contexts. ${ }^{5}$ Because the Epic Cycle survives, for the most part, in the form of Proclus' short summaries, the intertextual relation can almost exclusively be seen as related to more or less fixed, and often recombined, narrative sequences. There is considerable agreement, for example, that Patroclus' role and death in the Iliad is modelled on Antilochus', as narrated in an unattested *Memnonis (either a poem or a song-tradition) which was later to be integrated in the (attested but lost) Aethiopis. Yet no text is there to compare with the Iliad. ${ }^{6}$ Due to the defective state of the evidence, thus, such claims cannot usually extend to a demonstration of intertextual connections specifically emerging on a verbal level, as can be done in fully literate contexts. ${ }^{7}$ This is perhaps one important reason why oralism and neoanalysis have found a common ground in accounting for intertextual phenomena.

A qualitatively different type of interaction relates to the often explicit evocation of mythical material falling outside the principal poetic focus, which is deployed for

3 Emblematically G. NAGY (1979) 42: 'when we are dealing with the traditional poetry of the Homeric (and Hesiodic) compositions, it is not justifiable to claim that a passage in any text can refer to another passage in another text', for an early reaction cf. J. S. CLAY (1983) 244-7. Those scholars who hold that the authors of the Homeric poems composed with the aid of writing over an extended period see no difficulty in pinpointing the Odyssey's direct references to the Iliad; cf. esp. v. Di Benedetto (2001), M. L. WeSt (2014) $26-7,70-7$. For a thorough discussion of the problems at stake see B. CURRIE (2016) 1-38.

4 See especially G. DANEK (1996), (1998), (2010), (2016); K. DOWDEN (1996), (2004); B. CURRIE (2006), (2012), (2016); C. TSAGALIS (2008), (2011); J. BURGESS (2006), (2009), (2012), (2017); M. FINKELBERG (2011); articles in Ø. ANDERSEN and D. HAUG (eds) (2012), and in F. MONTANARI, A. RENGAKOs and C. TSAGALIS (eds) (2012), E. J. BAKKER (2013) 157-8.

5 On 'Neoanalysis' see w. KULlMANN (1991), M. WILlCOCK (1997); on its most recent developments see the contributions to F. MONTANARI, A. RENGAKOS and C. TSAGAlis (eds) (2012), J. BURGESS (2012), (2017), B. CURRIE (2016).

6 Cf. most recently B. CURRIE (2016) 55-72, with literature. For critiques see M. L. WEST (2003), A. KELLY (2006), (2012).

7 On proposed verbatim allusions, and especially on $\mu \varepsilon \dot{\gamma} \alpha \varsigma \mu \varepsilon \gamma \alpha \lambda \omega \sigma \tau i$ (Il. 18.26, of Patroclus, allegedly transferred from the context of Achilles' death, cf. Od. 24.40) see B. CURRIE (2016) 71-2, with literature. 
the purposes of the new context (e.g. references to the Theban war in the Iliad). ${ }^{8}$ The boundaries between the two kinds of interaction - re-use of a preceding composition recognisable as such vs. simple evocation and re-use of external mythical material likely present in song-traditions - are not always easy to draw in practice, but the one main difference is that only in the second case is the alien context evoked explicitly and unequivocally. Clearly, references to the shared mythical or epic-traditional knowledge and allusion to a specific composition are at the opposite ends of a theoretical scale of orality / 'textual' fluidity vs. literacy / textual fixity, but to what extent such a spectrum is reflective of the historical reality of archaic Greek epic remains, of course, a matter of debate. ${ }^{9}$

For the purposes of the present contribution, it is important to note that the type of interaction based on recognisably though implicitly transposed narrative sequences of the type Antilochus' death in the ${ }^{*}$ Memnonis $\rightarrow$ Patroclus' in the Iliad is difficult to pin down between the Iliad and the Odyssey, even if we do have the texts to compare. For the Odyssey 'never repeats or refers to any incident in the Iliad' ('Monro's law')..10 Yet the Odyssey (like the Iliad) repeatedly alludes to, and makes productive use of, extra-Odyssean material which the audience must have been familiar with (nostoi of the Achaeans - and especially of Agamemnon -, Heracles' deeds, catalogic poetry on heroines, the sack of Troy, Odysseus' earlier and later life, etc.)." D. L. PAGE notoriously took this circumstance as evidence that the Odyssey was unaware of the Iliad..$^{12}$ Some of the ancients do not seem to have considered the question in such negative terms: as the scholion goes, 'the Odyssey is rightly called a fulfilment ( $\alpha v a \tau \lambda \dot{\eta} \rho \omega \sigma \varsigma \varsigma)$ of the Ili$a d$, for what he [Homer] left aside there, he says here. ${ }^{13}$ In the context of the prevailing modern Unitarian views of disjunct authorship, this concept of àva $\lambda \lambda \dot{\eta} \rho \omega \sigma \iota \varsigma$ has been enriched and reframed in terms of a competitive emulation, on the Odyssey's poet part, of the monumental predecessor. ${ }^{14}$ Whether or not this is enough to explain away the

8 This is the interaction generally privileged by G. DANEK (1998) 26: 'Es wird sich immer wieder erweisen, daß mit der Evozierung von Material, dessen Kenntnis beim Hörer vorausgesezt ist, nur die inhaltliche Komponente erfaßt ist, wohingegen der sprachliche Aspekt, und mit ihm die kleinsten Details der Handlung, ausgeklammert blieben, da die Tradition einer mündlichen Ependichtung in der Regel mit dem Konzept der (inhaltlich festgelegten) 'Geschichte', und nicht mit dem eines fixierten Textes operiert'. The contributions to C. TSAGALIS (ed) (2014) explore the case of resonances of Theban mythological material in the Homeric poems; see also J. BURGESS (2017), against the individuation of a specific ${ }^{*}$ Meleagris as a background to Phoenix's tale in Iliad 9.

9 Recent attempts at offering theoretical and terminological distinctions between types and degrees of intertextuality in early Greek epic include C. TSAGALIS (2011) 221-3 and B. CURRIE (2016) 33-6.

10 D. B. MONRO (1901) 325, referring to B. NIESE (1882) 43-4. B. CURRIE (2016) 70-1 holds that the same principle (avoidance of explicit reprise) applies to the Iliad's interaction with the *Memnonis.

11 Most thoroughly treated by G. DANEK (1998), see further M. L. WEST (2014) 27-32, B. CURRIE (2016) 47-55.

12 D. L. PAGE (1955) 58-9; cf. J. BURGESS (2006) 164 n. 40; B. CURRIE (2016) 71.

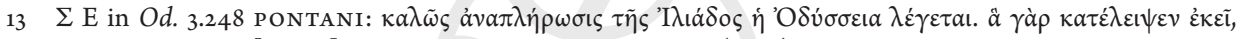
$\dot{\varepsilon} v \tau \alpha \tilde{v} \theta \alpha \lambda \dot{\varepsilon} \gamma \varepsilon$ l, cf. [Long.] 9, 13 and see further F. PONTANI (2010) $40 \mathrm{ad} \Sigma \mathrm{HM}^{\mathrm{a}}$ in Od. 3.103 .

14 Cf. F. JACOby (1933) 159-61, A. HeUbeCK (1954) 92, J. S. CLAY (1983) 244-7, R. B. RUtherford (1993) 38 n. 2, S. SAÏD (2011) 373-9, M. L. WEST (2014) 27, B. CURRIE (2016) 39 n. 5 and 70-1 (emulation not excluding joint-authorship), G. DANEK (2016) 131-2. The connection between the ancient insight and modern This material is under copyright. Any use outside of the narrow boundaries of copyright law is illegal and may be prosecuted.

This applies in particular to copies, translations, microfilming as well as storage and processing in electronic systems. (c) Franz Bteiner Secliage istutteghatg2020 
absence of explicit evocations of Iliadic contexts, the individuation of the specific connections that should bear witness to such creative interaction remains problematic. Indeed, recent scholarship working within an oralist framework has paid less attention to the possibilities of intertextuality between the Iliad and the Odyssey than to the interaction between each of the Homeric poems and preceding and unattested compositions, song-traditions, and/or mythical material..$^{15}$

At a general level, the isolation of the two poems is an important obstacle, for it often makes it quite difficult to decide whether a recurring item is traditional, imitated, or both. The problem is particularly acute in the case of alleged verbatim 'quotations', as they almost invariably involve formulaic expressions, or at least traditional diction - the stronghold of oralism. Somewhat paradoxically, it is here that most of the recent work on intertextuality between the two poems has focused, because the Homeric corpus is vast enough to permit a reasonable assessment, based on frequency, of the potential degree of traditionality of a given expression. ${ }^{16}$ Yet it remains unclear how such allusions (always debatable) should be framed within the traditional formulaic technique with which the composers worked. M. PARRY and his most eager followers have rightly been faulted for downplaying the semantic and aesthetic significance of the poets' formulaic language, but this is not to invalidate the conclusion that repeated expressions should in the first instance be held to have been, if not actually traditional, at least perceived as such by the audience. ${ }^{17}$

More to the point concerning our test-case, as we will see, is a focus on type-scenes and traditional 'themes'. Through examples of uneven plausibility, it has been maintained that if the poet of the Odyssey deploys a scene (or narrative sequence) highly similar to one found in the Iliad with analogous purposes (or meaningfully varied against the background of the posited 'source'), the case for imitation becomes the most probable one, particularly so if they are found in a comparable position within the narrative structure of the poems. ${ }^{18}$ Again, however, objections can easily be raised because one cannot exclude that this too was typical and occurred in other poems or performances

conceptions is exemplified by J. S. CLAY (1983) $244 \mathrm{n}$. 8, who describes the scholiast's phrasing as a 'formulation' of Monro's law.

15 For fully literate perspectives assuming fixed written texts cf. above n. 3 .

16 From different standpoints on Homeric composition and fixation, cf. P. PUCCI (1987), M. KORENJAK (1998), S. L. SCHEIN (1999), V. Di BENEDETTO (2001), E. J. BAKKER (2013) passim, esp. 157-69, B. CURRIE (2016) $45-6,224-5$.

17 On current impasses concerning the post-Parryan definition of 'formula' and 'formulaic expression' see $\mathrm{M}$. FINKELBERG (2004), R. FRIEDRICH (2011), C. BOZZONE (2014) 11-24. In general cf. J. B. HAINSWORTH (1993) 1-31, esp. 16-7 on 'the possibility that genuine formulas appear in our texts only once'. The 'interformularity' model developed by E. J. BAKKER (2013) 157-69 starts form oralist foundations and seeks to establish a scalarity of contextual restriction in formulaic expressions so as to individuate semantically marked repetitions. The model is criticised by A. KELLY (2015) 79-81, not least because its reliance on G. NAGY's crystallisation theory - similarly to P. PUCCI (1987) - undermines the contention of uni-directional imitation between passages or texts (see further below n. 25). Note that the comparable approach of $\mathrm{v}$. Di BENEDETTO (1998), who distinguishes between 'internal' (i.e. idiosyncratic) and 'external' (inherited/ traditional) formularity takes, instead, an entirely literary perspective envisaging fixed written texts.

18 Especially A. HEUBECK (1954), K. USENER (1990), R. B. RUTHERFORD (1993), B. CURRIE (2006), (2016) $39-47$.

$$
\begin{gathered}
\text { This material is under copyright. Any use outside of the narrow boundaries } \\
\text { of copyright law is illegal and may be prosecuted. } \\
\text { This applies in particular to copies, translations, microfilming } \\
\text { as well as storage and processing in electronic systems. } \\
\text { (c) Franz Bueiner Seeliagestyteglatg2020 }
\end{gathered}
$$


to which we have no access. More critically, even when the strength of the similarities makes a casual resemblance due to a sharing in traditional techniques unlikely for the modern critic, it is not clear how far the ancient audience was meant to spot a reference to the Iliad, whilst the possibility of an 'unconscious' imitation cannot be excluded. ${ }^{19}$

While proof or certainty in such intertextual matters should not be expected, and much depends on the critic's stance toward the Homeric question, there are no apparent reasons to deny that imitation, emulation or allusion can take place in oral or orally-derived contexts. ${ }^{20}$ Concerning the Odyssey's possible relation to the Iliad, the main issues today are how to detect and distinguish these phenomena; how to treat our examples without downplaying the traditional techniques that served the poems' performance context; and, finally, to ascertain what their implications are for our understanding of the interaction between composer and audience. ${ }^{21}$ The latter aspect is central, though often neglected, and two general possibilities should be mentioned at this stage. First, the audience or readership may perceive, and thus bring into being, an intertextual connection which the composer did not mean to produce (or did produce unconsciously, cf. above n. 19). But it is the reverse situation that perhaps deserves to be further explored in an early Greek context: there may be cases where the imitation has a raison d'etre of its own; where it carries, that is to say, a desired effect with it, without this effect being necessarily related to the audience's recognition of the source. A 'palimpsest' effect may well be present, but its being perceived by the audience may not be at the forefront of the composer's intentions. ${ }^{22}$ Naturally, this does not preclude that the poet's endeavour is better understood by considering the imitated text. In such a case, we seem to find a disconcerting disjunction between composer, who makes productive use of his source, and auditor, who may not be induced to perceive the process. Yet it may well turn out that this disjunction is in effect a function of the relation between singer and audience, and specifically of the status of the singer and his song, as was typical (and expected) in an early Greek orally-derived context.

19 See for instance G. DANEK's (2016) critique of B. CURRIE's (2006) case for an allusion to Priam's journey to the Achaean camp in Il. 24 in Odysseus' journey to Alcinous' palace in Od. 6-7, restated in B. CURRIE (2016) 42-6.

20 Cf. B. CURRIE (2016) 4-6, referring to the findings of G. DANEK and z. ČOlaCović on South-Slavic heroic song.

21 The present attempt may thus be seen as partially counterbalancing B. CURRIE's explicit renounce, given the state of research, to a treatment that makes full justice both to the traditional art and to specific intertextual mechanisms, cf. B. CURRIE (2016) 8.

22 On early Greek epic intertextuality as 'palimpsest' see C. TSAGALIS (2008) and G. DANEK (2010), who adapt the metaphor by G. GENETTE (1982) to an 'oral' context: the 'palimpsestuous' nature of the early Greek texts (their 'erasing and re-writing') is not manifest through specific interactions with fixed compositions, but with mythical and epic material present in oral traditions.

This material is under copyright. Any use outside of the narrow boundaries of copyright law is illegal and may be prosecuted.

This applies in particular to copies, translations, microfilming

as well as storage and processing in electronic systems. (c) Franz Bteingr Secliageistiteglatg2020 


\section{Preliminary remarks on Il. 7.443-64 and $\mathrm{Od}$. 13.125-60}

Our case-study centres on the dialogues between Zeus and Poseidon at Il. 7.443-64 and Od.13.125-60. G. s. KIRK, in the Iliad's Cambridge commentary, sees the Odyssean scene as the model for the Iliad passage, which he deems 'an addition'. In the Lorenzo Valla / Oxford commentary to the Odyssey, A. HOEKstra judges the Odyssey scene 'a flat copy of similar Olympic scenes in the Iliad'.23 G. S. KIRK, in effect, offers the latest attempt at questioning the authenticity of the Iliad passage, suspected since antiquity. Relying on the excellent defenses available (ancient and modern), we take the liberty of giving its authenticity for granted. ${ }^{24}$ Nor shall we entertain the notion of a diachronically discernible mutual influence between evolving 'Iliadic' and 'Odyssean' traditions, though such an interpretation could easily explain away the contrasting views of G. S. KIRK and A. HOEKSTRA, and is compatible with our conclusion that an intertextual relation is at work here. ${ }^{25}$ Each of the two scenes will be assessed as an organic part of a coherent and relatively synchronic creation by a composer well-stepped in traditional techniques. $^{26}$

We will proceed with an analysis of similarities and differences in the light of the use of epic traditional techniques and will discuss, on that basis, whether we should see this as a case of conscious imitation. $K$. USENER has offered the most complete comparative account of our two scenes, and will be an unavoidable point of reference. ${ }^{27}$ His book sought to highlight the dependence of the Odyssey on the Iliad in a number of cases, for each of which the author tries to demonstrate that the Iliadic context is an original cre-

G. S. KIRK (1990) 289, A. HOEKSTRA (1988) 173.

24 G. S. KIRK (1990) 288-89. According to $\Sigma$ A in Il. 7.443-64 Zenodotus, Aristophanes and Aristarchus athe-

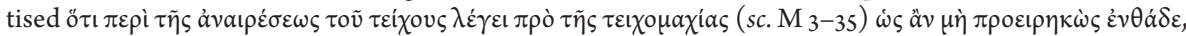
'because (Homer) speaks about the destruction of the wall before the Teichomachy (Il. 12.3-35) as if he had not spoken about it in advance here'. But 7.449-450 are echoed at 12.4b-6, 7.459-460 at 12.15-16 and 7.462 at 12.31. Cf. $\Sigma$ bT in Il. 7.464, quoted by M. L. WEST in his apparatus; K. USENER (1990) 75-7; and note that the argument by P. FINGLASS (2006) against $\mathrm{Il}$. 7.466-77, which is convincingly countered by A. KELLY (2008), presupposes the authenticity of the divine scene: cf. P. FINGLASs (2006) 194, A. KELLY (2008) 13-14.

25 This view complies with G. NAGY's crystallisation theory concerning the Homeric poems' composition; for intertextuality within such a framework see especially P. PUCCI (1987), J. MARKS (2008), C. TSAGALIS (2008), (2011), E. J. BAKKer (2013), E. BARKer and J. CHRISTENSEN (2014). Criticism in G. DANeK (2012), A. KELLY (2015), B. CURRIE (2016) 15-7.

26 Cf. J. BURGESS (2006) 162: 'the infinite regress of many postmodern approaches, in which everything potentially connects in an endless intersection of "texts," is inimical to reaching an understanding of the poetics at work.' J. BURGESs's critique is generally directed to models drawing on J. KRISTEVA (1969); it is here extended to their deployments within the 'evolutionary' concept of the genesis of the Homeric poems.

27 K. USENER (1990) 67-80; an early and succinct comparison was offered by K. SITTL (1882) 62, 127; S. E. BASSETT (1933) 306-7, and H. ERBSE (1972) 145 note that the destruction of the Phaeacian ship after the divine discussion is paralleled at Il. 12.3-33; J. MARKs (2008) 50-1 briefly compares the two scenes - and R. P. MARTIN (2016) 84, the two destructive interventions by Poseidon - without discussing the possibility of an intertextual connection. A. M. BOWIE (2013) 118-9 lists Il. 7.445-64 as a parallel alongside four further divine episodes, including one in the Standard Babylonian Epic of Gilgameš (Tablet VI.80-114 GEORGE).

$$
\begin{gathered}
\text { This material is under copyright. Any use outside of the narrow boundaries } \\
\text { of copyright law is illegal and may be prosecuted. } \\
\text { This applies in particular to copies, translations, microfilming } \\
\text { as well as storage and processing in electronic systems. } \\
\text { ○ Franz Bteiner SeetliagerStvteglatg2020 }
\end{gathered}
$$


ation and that the Odyssey parallel is derivative. Many of his conclusions are appealing, but he could not avoid the usual charge of subjectivism, while his methodology entails an unsatisfactory treatment of the traditional features of epic composition. ${ }^{28}$ We will thus attempt a fresh comparison from a different perspective, and consider in turn the shared traditional language, the scenes' structural purpose, and how the gods' characterisation, as shaped by traditional forms of composition, is made to fit with each poem's narrative and theological context.

Let us first recall the content of the two scenes. Towards the end of Book 7 of the Iliad, the Achaeans are building their fortification during the truce that was agreed upon to collect and dispose of the dead. The construction is a mighty work, which the gods look upon. Suddenly, Poseidon addresses Zeus, and complains that the Achaeans have forgotten to offer proper hecatombs. Moreover, he goes on, the glory ( $\kappa \lambda \varepsilon \dot{\varepsilon} \varsigma$ ) of this wall will obscure his own and Apollo's glory, who had painstakingly built the walls of Troy for king Laomedon. Zeus reassures Poseidon about his glory, and states that the sea god shall destroy the construction and make it disappear after the war is over. One important function of this scene is to highlight, through the divine attention, the crucial importance of the wall for the forthcoming events in the Iliad, whose core is constituted by the Trojan siege of the Achaean camp in Books 11-18.

In the Odyssey passage Odysseus has just landed safely and rich in Ithaca. The Phaeacian ship that brought him is heading back home, when Poseidon complains to Zeus that things have not quite gone as he would have liked. Not that he expected Odysseus not to get home safely, he says, for that was granted by Zeus, but at least he thought Odysseus would reach Ithaca 'suffering many pains', and not peacefully sleeping amid riches. $\mathrm{He}$ blames the Phaeacians, his own progeny, and fears for his honour ( $\tau \iota \mu \eta \dot{)}$ among gods and men. As in the Iliad, Zeus reassures his brother concerning his honour and rank, and concedes revenge. In the Iliad we had one speech each, here the pattern is doubled. As Poseidon exposes his plan to smash the Phaeacian ship and cover the Phaeacian city up, Zeus modifies the proposal, and delays action against the ship until after its arrival at sight-seeing distance from the island. Zeus' proposal leads to the following scene, which concludes the Phaeacian part of the Odyssey. The poem thereby departs from the Phaeacians, and from the theme of Poseidon's wrath, as Odysseus finally arrives to Ithaca.

\section{Shared Traditional Elements}

We may start our comparison by looking at the resonances on a verbal level, all of which appear to have a traditional background, being all widespread items in epos. This applies of course to the cletic Zeṽ $\pi \dot{\alpha} \tau \varepsilon \rho$ 'father Zeus' at Il. 7.446 and Od. 13.128 (21 x Il., 11 x Od.,

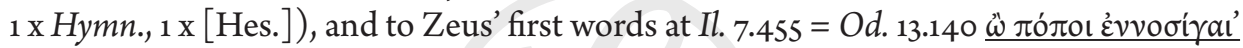

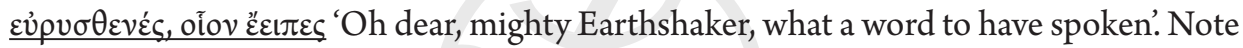




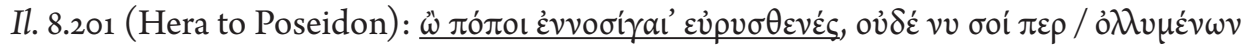

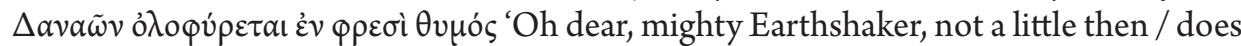

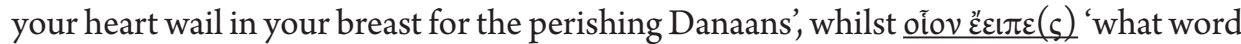
to have spoken' recurs 9x Hom. It is worth noting, still, that, in Homer, only in these two contexts and with reference to the Achaean wall and Phaeacia (Il. 7.462, 12.31 and Od.

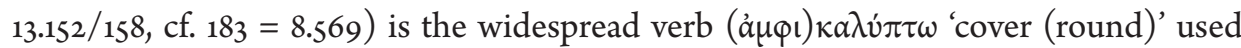
beyond its basic meaning and its normal formulaic contexts to signal a cosmic destruction and disappearance. This deployment, however, recurs in Hesiod's myth of the races,

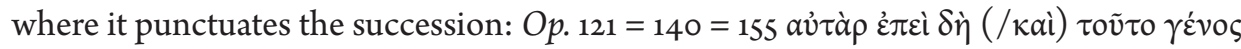

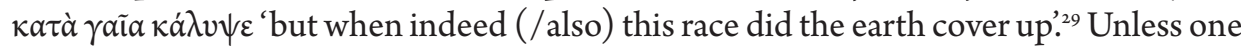
assumes that Hesiod took this usage over from one or more of our extant Homeric passages, this evidence speaks for a traditional (if situationally restricted) status of ( $\dot{\alpha} \mu \varphi \mathrm{l})$ $\kappa \alpha \lambda \dot{\tau} \pi \tau \omega$ as a signal of cosmic destruction.

Just as the formulae are unmistakably traditional, so too is the narrative situation, which can be defined as 'divine complaint scene..$^{\circ}$ In these scenes, a deity makes a complaint and/or a request to Zeus, sometimes on account of the human protégé. Usually Zeus triggers some action, often with some delay. ${ }^{31}$

K. USENER does recognise that both scenes belong to a given typological framework, and is right to point out that these are the only two such scenes featuring Poseidon and Zeus..$^{32}$ Indeed, the 'indirect' dialogue between the two at Il. 15.173-218 (Poseidon and Iris) is typologically different, while at $I l .20 .13-31$ there is no direct complaint or request. Yet precisely the recurrence at $I l .20 .15 \mathrm{~b}$ and $O d .13 .127 \mathrm{~b}$ of the introductory iunctura $\Delta$ iò

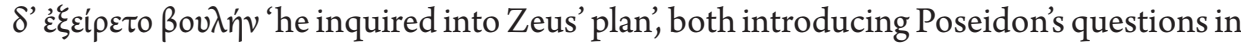
two seemingly unrelated scenes, makes it plausible that the epic repertoire (fixed or not) featured more dialogues between the two brothers than those which survive.

The fact that in the Iliad Poseidon complains about his glory ( $\kappa \lambda \dot{\varepsilon} \circ \varsigma)$ and in the $O d$ yssey about his honour ( $\tau \iota \mu \eta \dot{)}$, another of $\mathrm{K}$. USENER's points, ${ }^{33}$ could equally be considered of relatively small significance for a direct relation. Our examples show that the matter of $\tau \iota \mu$, not unexpectedly, is important and widespread in the divine system of

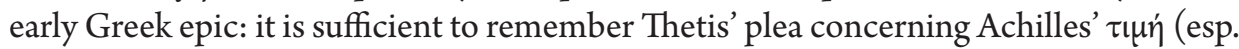

$29(\dot{\alpha} \mu \varphi \mathrm{l}) \kappa \alpha \lambda \dot{v} \pi \tau \omega$ is most commonly used in the context of sacrifice; or as death, darkness, night, pain or sleep overcomes someone (often his / her eyes); cf. H. W. NORDHEIDER in LfrgE II.1315-8. Note the the-

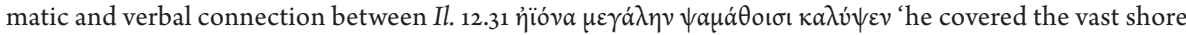

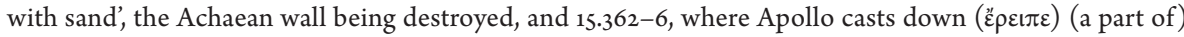
the wall as a child playing with sand $(\psi \alpha \dot{\mu} \mu \theta 0 v)$ by the sea.

30 B. CURRIE (2016) 193-8 discusses a number of elements in the typology as present in the Iliad and considers Near Eastern parallels.

31 Homeric cases include Il. 1.493-530 (Thetis requires Zeus' help on account of Achilles), 5.753-67 (Hera complains about Ares), Il. 5.868-906 (Ares, wounded by Diomedes, complains to Zeus about Athena), Il. 9.510-2 (the reviled 'Litai' complain to Zeus), Il. 21.505-14. (Artemis to Zeus about Hera); Od. 1.44-102, 5.5-43 (Athena about Odysseus), Od. 12.374-90 (Helios complains about Odysseus' crew, who are eating his cattle), Od. 24.472-88 (Athena, worried about civil strife in Ithaca).

32 K. USENER (1990) 71: 'unter der Götterklage wiederum nimmt die Beschwerde des Poseidon - als Unterart der Sub-Gattung 'Götterklage' - eine besondere Stellung ein'.

33 K. USENER (1990) 71.

This material is under copyright. Any use outside of the narrow boundaries of copyright law is illegal and may be prosecuted.

This applies in particular to copies, translations, microfilming as well as storage and processing in electronic systems. (c) Franz Bteiner Stecliage ItVtuteglatg2020 
Il. 503-8, 515-6), Zeus' promises as he fetches allies against the Titans in the Theogo$n y$ (Th. 392-6), or Hera's protests as she perceives that her labours against the Trojans might prove vain and appeals to her rights and status (Il. 4.58-61, cf. 18.360-7). Posei-

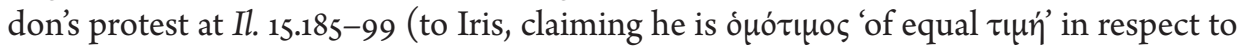
Zeus) shows that the sea god was especially sensible to the issue. ${ }^{34}$

On the whole, thus, the hypothesis of a direct reception is unnecessary to explain the coincidences on the level of formulae and of the type-scene.

\section{The Scenes and the Poems: a Structural Imitation}

Yet there are important aspects of the scenes' content and structural position that have not been sufficiently explored, but could in fact strengthen the case for a direct reception. They relate to the subject of the divine discussion, the Achaean fortification and Phaeacia, and their pivotal function within the poems. For just as the Achaean fortification is essential for the plot of the Iliad in that it permits the central reverse siege (Books 11-18) ultimately caused by Achilles' withdrawal and leading to Patroclus' death and successive events, ${ }^{35}$ so is Scherie crucial for the Odyssey's narrative organisation. It has long been seen that it is around (and within) Odysseus' stay among the Phaeacians (Books 6-12) that the poet organised the disposition of the major narrative blocks of his epic. ${ }^{36}$

Now in our two scenes Poseidon and Zeus discuss and then agree on the obliteration of the Achaean wall and of the Phaeacian island. Both dialogues, indeed, provide the theological background to a remarkable strategy developed in both poems, namely that of signalling the disappearance of the poetic object that marks the specificity of each poem's narrative structure. Homeric scholarship has marvelled at this strategy since antiquity, signally as regards the Achaean wall, whose destruction is accounted for at length in the famous external prolepsis in Book 12 (Il. 12.3-33). ${ }^{37}$ Especially noteworthy is the possibility that a metapoetic operation is at work here: ancient and modern critics agree that the poet of the Iliad, by anticipating and then proleptically portraying the wall's obliteration, highlights the converse capacity of his own heroic poetry to perpetuate memory of $\kappa \lambda \dot{\varepsilon} \alpha \dot{\alpha} v \delta \rho \tilde{\omega} v$ ('glorious deeds of men') beyond destruction..$^{38}$

On divine timai see esp. J. RUDHARDT (1981) 227-33, J. S. ClAY (2006), R. PARKER (2011) 84-6.

On the Achaean wall see K. Reinhardt (1961) 190-206, M. L. WEST (1969), R. SCOdeL (1982), M. DAVIES (1986), I. J. F. DE JONG (1987) 88-9, T. W. BOYD (1995), J. MAITLAND (1999), G. KLOSS (2001), J. PORTER (2011), J. S. CLAY (2011) 56-9; C. O. PACHE (2014) 291-6.

6 See especially T. KRISCher (1985), A. F. GARVIE (1994) 18-31, I. J. F. DE JONG (2001) 149-52, M. L. WEST (2014) 129-35.

On ancient interpretations of Homer' Achaean wall cf. J. PORTER (2011).

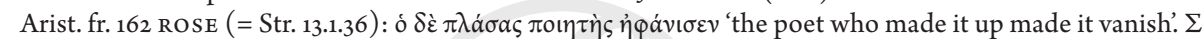

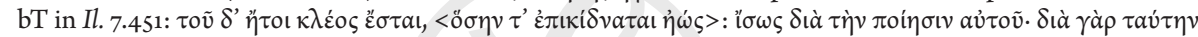

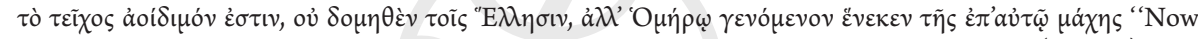
the fame of this will last <as long as dawnlight is scattered >': Probably owing to the making ( $\pi$ oín $\sigma \varsigma$ ) of it; for it is on this account that the wall is a famous object of song, not as something made by the Greeks, but as an object that was brought into existence by Homer for the sake of the battle to be waged over it.' (transl.

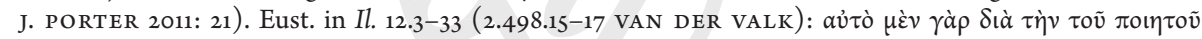
This material is under copyright. Any use outside of the narrow boundaries of copyright law is illegal and may be prosecuted.

This applies in particular to copies, translations, microfilming as well as storage and processing in electronic systems. (c) Franz Bteiner Secliage ItVtutglatg2020 
Following the ancient view, well summarised by Eustathius, scholars have generally surmised that the 'blockade' of Phaeacia has the primary objective, for the poet, of impeding future search for an island which he probably invented; and of making it disappear as the 'otherworldly' part of Odysseus' adventures comes to an end..$^{39}$ But the comparison with the Iliad permits us to say more. Although the Odyssey poet does not portray the destruction of Scherie, and leaves the Phaeacians (and the audience) in suspense about the fate of the island, he uses the divine dialogue with an identical metapoetic purpose to his predecessor. ${ }^{40}$ Again, to reflect on the divinely-ordained destruction of the central poetic object means to mark the distance between the epic universe of the past and the present of the audience, but also, and crucially so, to highlight the importance of this object for the shape of the narrative. Like in the Iliad, this is achieved by showcasing Poseidon's role as the resentful god of natural catastrophes. But in the Odyssey, the divine scene further signals that the sea god's activity as the main divine opponent of the wandering hero has come to an end, according to Zeus' designs, and precisely when Phaeacia has exhausted its role. Poseidon's re-appearance thus terminates the narrative thread on Phaeacia which began with Odysseus' formidable arrival at the island in Book 5 - in spite of Poseidon's opposition. ${ }^{41}$ This encircling technique contributes to marking off the Phaeacian episode as central for the poet's plans: it is worth recalling, in this respect, that Poseidon's speech flags up an alternative course of action for the narrative as a whole, by pointing out that things might well have gone otherwise without the Phaeacian hospitality and escort (Od.13.131-8). ${ }^{42}$ In this way, and very much like the Iliad divine dialogue does in respect to the Achaean fortification, the poet advertises and reinforces his own version of the story, in which Scherie plays the fundamental structural function.

It is also important to consider that these scenes are both positioned at crucial and mutually symmetric turning points in the narrative, in theological and diegetical terms.

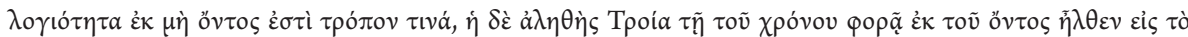
$\mu \eta \delta \dot{\varepsilon} v, \dot{\alpha} \varphi \alpha v \_\sigma \theta \tilde{\varepsilon} \sigma \alpha$. 'Thanks to the poet's eloquence, the Achaean wall in some way is, having emerged out of nothing, while the real Troy, which formerly was, in the course of time came to naught, having vanished.' (transl. J. PORTER 2011: 17). Cf. I. J. F. DE JONG (2006) 199-202, J. PORTER (2011) 12-34 (on the Achaean wall) and J. НАUвоLD (2014) 335-7 (against the foil of Babylonian flood destruction narratives).

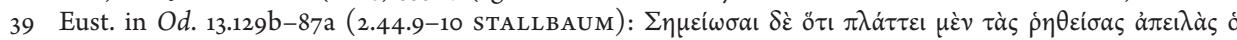

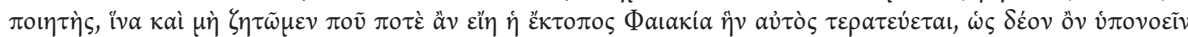

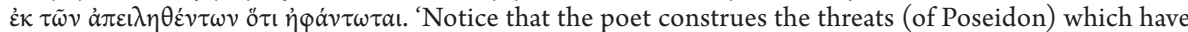
been foretold (viz. by Alcinous/Nausithoos), so that we may not even investigate where the out-of-theway Phaeacia, about which he himself has been talking marvels, lay at that time, as if binding us to suspect from the uttered threats that it has vanished.' See e. g. H. ERBSE (1972) 145-8, I. J. F. DE JONG (2001) 319-21, J. MARKS (2008) 47-8, M. L. WEST (2014) 231-3, all of whom take different positions on the reading of 13.158 , on which see below n. 46 .

40 Cf. S. E. BASSETt (1933) 306-7: 'The poet, having created the delightfully interesting Phaeacians (...) treats them as he did another of his creations, the Achaean Wall.'; the assumed visibility of the petrified ship being 'a monument to the (...) great achievement of Homer himself in creating the Phaeacians'. s. E. BASSETT was a strong asserter of single authorship for both poems.

41 Cf. J. MARKs (2008) 36-61; on Poseidon in the Odyssey's theology see the discussion by E. J. BAKKER (2013) 114-34. 
We have just seen that in the Odyssey the divine conversation comes when the 'central invention', the Phaeacian island, has finished to serve its narrative purpose (Odysseus is home), and signals the end of Poseidon's anger within the limits of the plot. In the Iliad, the dialogue is portrayed while the wall is being built, and just before Zeus finally starts to set in train his plan against the Greeks at the outset of Book 8, to the displeasure of the pro-Achaean gods.

Whether or not one believes that the Achaean wall and the Phaeacian island were utterly invented for the purposes of the Iliad and the Odyssey, there is virtually no denying that these poetic objects (both destined to disappear) are central to the specific large-scale narrative strategies that underpin the poems. If one abides by the communis opinio that the Odyssey is later than the Iliad (and composed by another poet), ${ }^{43}$ the question to ask here is whether the Iliad poet was the first, or the only one, to signal and comment upon the destruction of the decisive structural element of his narrative by using such a dialogue between Poseidon and Zeus. We should ask, that is to say, whether this is likely to have been a traditional device. The lack of other complete heroic poems is certainly regrettable here, as we are dealing more with questions of broad narrative structure at the level of a large-scale poem's narrative organization, than with formulaic or type-scenes patterns. Yet as the evidence stands, the archaic hexametric corpus and the testimonies to the Epic Cycle offer considerable evidence for divine scenes that structure epic plots, but the outlined analogies between Il. 7.443-64 and Od. 13.125-60 are certainly marked and isolated. ${ }^{44}$

If it is accepted that the balance of probabilities inclines toward a case of imitation, it is possible to view the Odyssey's striking silence concerning the outcome of Poseidon's menaces as a case of oppositio in imitando..$^{45}$ While the Iliad gives considerable emphasis to the future annihilation of the wall, in an unusual departure from narrative conventions, the Odyssey poet may have chosen to do the opposite, construing a silence which is not dissimilar to Ajax's at Od. 11.563-4, 'more sublime than any words' ( $\pi \alpha v \tau$ c̀ v $\psi \eta \lambda$ ó $\varepsilon \rho o v \lambda o ́ \gamma o v$, [Long.] 9.3). ${ }^{46}$ This would match the reversal whereby the Iliad scene

43 For the linguistic case cf. R. JANko (1982) part. 82-3, 189; (2012), though see B. JONES (2012) and M. L. WEST (2012) 227-8; for literary argumentations see above n. 14, and in general $\varnothing$. ANDERSEN and D. HAUG (eds) (2012) on current positions concerning the relative chronology of early Greek epic.

44 To consider the rest of surviving epos: on a smaller scale, an Olympic scene representing the turning point of the entire plot is h.Merc. 321-96. The scanty evidence for the Epic Cycle includes a heavenly scene that may have preceded the decisive duel in the Aethiopis, cf. M. L. WEST (2013) 147-8, A. RENGAKos (2015) 307-8, 315; the doom of the lesser Ajax and of the Achaean fleet was possibly planned in heaven towards the end of the Iliou persis (Il. Pers. arg. 266-7 SEVERYNS) and/or at the beginning of the Nostoi (Apollod. Epit. 6.5). These cases have little in common with our two scenes. On the structural role of Olympic scenes in early Greek epic cf. J. MARKS (2008), (2016), s. ROMANO MARTín (2009) 15-78, C. TSAGALIS (2016), C. BONNET (2017), B. SAMMONS (2017), 177-209, B. BALLESTEROS PETRELLA (2017).

45 On this procedure see B. CURRIE (2016) 27 n. 172 (literature) and 337 (s.v. 'opposition in imitation') for discussion of possible cases.

46 This implies that we should trust the manuscripts of $O d$. 13.158 (though M. L. WEST prints $\mu \grave{\eta} \delta \dot{\varepsilon}$, cf. M. L. WEST 2014: 232 n. 144). From $\Sigma \mathrm{H}$ in Od. 13.152 DINDORF - the scholion clearly referring to 13.158, cf. $\mathrm{H}$.

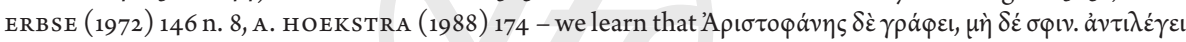

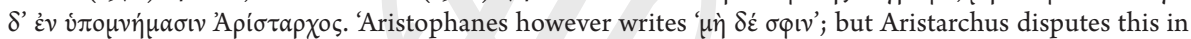
his Hypomnemata'. The conjecture has not entered the mss. tradition (unlike the variant $\mu \varepsilon \dot{\varepsilon} \tau \delta$ '́ 'and later'). This material is under copyright. Any use outside of the narrow boundaries of copyright law is illegal and may be prosecuted.

This applies in particular to copies, translations, microfilming as well as storage and processing in electronic systems. (c) Franz Bteiner Seeliagerstiteglatg2020 
is introduced as the wall comes into existence, while in the Odyssey Poseidon and Zeus debate as Scherie is about to disappear - from the poem at least.

\section{Tradition and Context: Imitation and Audience Expectation}

If one is willing to compare the poetic texture of our two divine dialogues, however, it is best to keep a neutral perspective, without giving in to the temptation of interpreting differences as resulting from adaptation. The presence of traditional mechanisms, to be sure, does not preclude the possibility of a direct reception, but since the compositional techniques at work are widespread in epos, and therefore unlikely to have been used in the Odyssey scene as a result of imitation of Il. 7.443-64, we should consider, in the first instance, how each passage deploys such techniques for its own purposes. This is helpful to understand how the poets interacted with the audience's horizon of expectations, and whether or not the audience was led to recognise the imitative process - if, in other words, we are entitled to speak of allusion.

One important difference between the two scenes is their setting: in the Iliad we find a divine collective scene, or divine assembly, introduced with the motif of the divine gaze (7.444), whereas in the Odyssey Poseidon addresses Zeus right away, and the dialogue is not set in a collective context. $\mathrm{K}$. USENER interprets this difference as a sign of Odyssean reception, claiming that in the Iliad 'the scene is better prepared. ${ }^{47}$ There is, however, a traditional compositional distinction between divine assembly scenes, where a plurality of gods is involved or said to be present, and the one-to-one dialogues. ${ }^{48} \mathrm{~A}$ neglect of this distinction prevents us from appreciating its role in a compositional perspective. Poseidon, talking in the divine gathering in the Iliad, describes the outrage as affecting the gods, viz. the divine community (esp. 7.447, 450); when it comes to the

It is misleading to emphasise that we have no means to tell whether Aristophanes' $\mu$ ' was a variant or a conjecture, as does J. MARks (2008) 56: we know of another case (Od. 2.70), where Aristophanes' text introduced a $\mu$ ' to solve a zetema, and this time the scholion (F. PONTANI 2007: 253) is positive about its

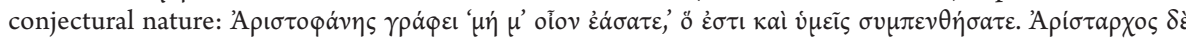

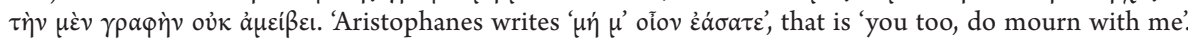
However Aristarchus does not change the reading.' Modern scholars and editors rightly follow Aristarchus at Od. 2.70 - cf. e.g. S. R. WEST (1981) 251; though in S. R. WEST (1988) 135 she is more benevolent to Aristophanes. On Aristophanes' Homer see R. PFeIfFer (1968) 173-7, and W. G. SLATER (1986) 205-10, who points out (p. 209) that 'it is not reasonable to think that in these places [scil. 2.70 and 13.158] Aristarchus rejected a simple text with Aristophanic authority', and concludes (p. 10) 'that Aristophanes was prone to alter the text or to accept others' alterations, knowing that there was no authority, when he wished to solve a zetema. For a list of other such apparent cases see W. G. SLATER (1986) 193 (on Od. 1.424) and 209. On Aristophanes' intervention on Od. 13.158 cf. already A. RÖMER (1924) 244-5.

47 K. USEner (1990) 72: 'Im Gegensatz zur Ilias, wo die Götter dem Geschehen zusehen, bringt Poseidon seine Klage in der Odyssee völlig unvermittelt vor; die Götter werden als Zuschauer nicht erwähnt, eine Rahmensituation wie in der Ilias ist nicht gegeben. Die Szene ist somit in der Ilias besser vorbereitet.'

48 Divine assemblies including onlooking gods: $\mathrm{Il}$. 4.4, 22.166, Od. 8.327. One-to-one divine dialogues (e.g., cf. below n. 52): Il. 1.502-28 (Thetis and Zeus), 7.23-43 (Athena and Apollo), 16.432-58 (Zeus and Hera), Od. 12.376-88 (Helios and Zeus), 24.472-87 (Athena and Zeus).

This material is under copyright. Any use outside of the narrow boundaries of copyright law is illegal and may be prosecuted.

This applies in particular to copies, translations, microfilming as well as storage and processing in electronic systems. (c) Franz Bteiner Secliage istutteghatg2020 
wall, he brings in Apollo too (7.452-53). ${ }^{49}$ Even so, Zeus discerns and exposes his brother's personal resentment, and reassures Poseidon about his individual $\kappa \lambda \varepsilon$ ś

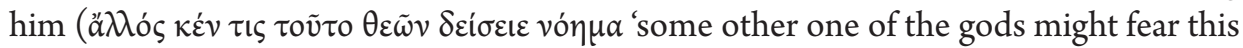

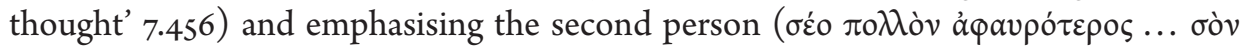
$\delta$ ' 7.457-8). By contrast, in the Odyssey's one-to-one dialogue, Poseidon focuses entire-

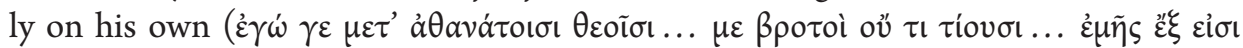

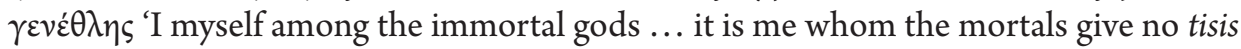
at all ... these who are of my own progeny' 13.128-30). Indeed, the Iliad's poet choice to set the dialogue in a collective context contributes to the greater tension of the scene.

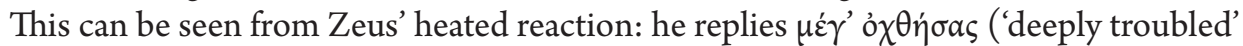
7.454), because the wall, which is crucial for his plan, is menaced in the assembly..$^{50}$ In the Odyssey, as Zeus' plan concerning Odysseus' return has been brought to completion, the one-to-one dimension permits the brothers' courteous exchange.

It is equally misleading to consider the 'doubling' of the dialogue pattern as a sign of emulation. ${ }^{51}$ The Homeric poems, in fact, portray divine dialogues that consist of one speech per character, and dialogues that develop through more exchanges. The compositional difference corresponds to the degree of negotiation involved in the discussion, whether a consensus is reached or a decision imposed..$^{52}$ In our case, we can perceive a contrast between the quick and firm reaction of Zeus in the Iliad, as the wall is at stake and Zeus is about to actively pursue an agenda which runs contrary to the pro-Achaean gods (including Poseidon), and the calm and lengthy process in the Odyssey, where the peaceful modification of Poseidon's idea goes hand in hand with the brothers' reciprocal statements of respect. In theological terms, indeed, the dialogue represents the resolution of the latent tensions between Zeus' plan and Poseidon's wrath against Odysseus. ${ }^{53}$

49 This has caused some disturbance (cf. G. S. KIRK 1990: 289), because at Il. 21.446-9 Poseidon has a different story to tell, whereby whilst he was building the walls for Laomedon, Apollo attended to the king's flocks. But this too is easily explained in terms of contextually-driven characterisation, for at Il. 7.452-3 Poseidon is opposing humankind to the gods as a group, whereas in the dialogue with Apollo his interest falls in the creation of an opposition and an axiology of power, seniority and prestige, of which the different roles are a clear function. For this type of impromptu manipulation of the past cf. Ø. ANDERSEN (1990), A. Kelly (2018).

50 On this expression cf. P. CHANTRAine (1999) 844, s. SCUlly (1984), H. W. NORdHeider in LfrgE III.903-4, A. KELLY (2007) 224-5, with occurrences. This speech introduction is neglected by J. MARKS (2008) 50-1, who questionably holds that Zeus is not irritated in the Iliad as 'the absence of such an animus from the Odyssey passage might argue against this interpretation.'

51 K. USEner (1990) 73: 'Die Aufforderung des Zeus zu einer milderen Reaktion des Poseidon erfolgt in einer Doppelung des Redeswechsels und stellt eine Korrektur des Odysee-Dichters dar'.

52 Homeric examples of divine 'simple exchange' (one speech each) include: Il. 5.756-67 (Hera and Zeus), 5.871-99 (Ares and Zeus), 8.200-12 (Hera and Poseidon), 16.433-58 (Hera and Zeus), 18.356-68 (Zeus and Hera), 19.100-12 (Zeus and Hera), 20.15-31 (Poseidon and Zeus), 20.114-44 (Hera and Poseidon), 20.292318 (Poseidon and Hera), Od. 12.376-88 (Helios and Zeus), 24.472-87 (Athena and Zeus). 'Articulated exchange' (two speeches each at least): Il. 1.539-68 (Hera and Zeus), 4.5-68 (Zeus and Hera), 14.189-213 (Hera and Aphrodite), 14.231-77 (Hera and Hypnos), 14.297-346 (Zeus and Hera), Od. 1.31-96 (Zeus and Athena).

53 Cf. above n. 41.

This material is under copyright. Any use outside of the narrow boundaries of copyright law is illegal and may be prosecuted.

This applies in particular to copies, translations, microfilming

as well as storage and processing in electronic systems.

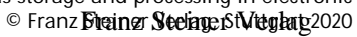


Each poet, thus, made a choice among the spectrum of options offered by the tradition, and each choice (divine assembly vs. one-to-one dialogue, simple exchange vs. articulated exchange) served the specific effect the poet was after. If there was imitation, as was argued in the preceding section, it left no mark on the compositional mechanisms pertaining to the scene. This holds as true for the similarities at work in the verbal resonances and the 'divine complaint' as it does for the differences in scene structure. The audiences of the Odyssean dialogue, therefore, were sent no readily identifiable signals that an interaction with the Iliad was taking place.

The latter may seem a paradoxical statement in an article arguing for imitation. In discussing sophisticated literature, it is surely important to keep in mind that authors tend to write with an 'optimal' audience in mind. That is to say, authors have an 'all-encompassing (...) egotistical view of the work of art.'54 In fully literate contexts, thus, the critic has the duty to dig deep into the compositional genesis of the work, uncovering sources that the average audience would not identify. Similarly, we could leave the matter here, conclude that the Odyssey poet engaged in conscious imitation with the Iliad without attempting to elicit recognition, and explain this 'reticence' in terms of a learned operation whereby the poet expected only the most gifted auditors to fully enjoy the intertextual game. Again, however, this would mean to underestimate the orally-derived dimension which shaped the poems as we have them. In fact, that dimension may provide a key to fully understand the Odyssey's imitative act, in our case at least.

The authority of the Homeric poet relies, importantly, on what R. SCODEL has aptly called the 'rhetoric of traditionality.'s5 The singer tends to factor in, and promote, the audience's expectation that what is being narrated is true in the sense that it is known, a part of the tradition. In the case of Phaeacia, whether or not the island was in fact traditionally part of Odysseus' story when the poet composed, an ignorant auditor was led to believe that it was. One important aspect of this inclusive strategy is that, unlike in many characters' narratives within the epics, the main narrator's accounts are meant to seem totally disinterested, and not to provide any source for his knowledge, except for the divine Muse. And of course, there is 'only one significant practical difference between bardic narratives and those of less authoritative characters: the bard's freedom to report the doings of the gods. ${ }^{36}$ In this perspective, it is only to be expected that the poet of the Odyssey should not strive to advertise his clever redeployment of the Iliad whilst narrating Poseidon's negotiation with Zeus. Quite apart from the (arguably varying) actual capacity of his historical audiences to recognise his act of imitation, the absence of specific clues in the scene's poetic texture should be seen as a function of this traditionally-oriented rhetoric..$^{57}$ The poet is content with reinforcing the worth of his own

V. Di BENEDETTO (2001) 7-8; cf. B. CURRIE (2016) 29-31 ('ideal listener'), with literature.

R. SCODEL (1997), (1998), (2002).

R. SCODEL (1998) 178; this is confirmed by the quick justification of the one exception at Od. 12.389-90.

According to B. CURRIE (2016) 28, 54, the identification of intertextual interactions undermines the notion of an all-encompassing 'rhetoric of traditionality', insofar as it signals the narrator's self-conscious attitude. This may be true when 'allusion' (i. e. imitation meant to elicit audience response) is demonstrated. This material is under copyright. Any use outside of the narrow boundaries of copyright law is illegal and may be prosecuted.

This applies in particular to copies, translations, microfilming as well as storage and processing in electronic systems. (c) Franz Bteiner Secliage istutteghatg2020 
version of the story, namely the structural centrality of Phaeacia. It is in the specific way in which this is done, we have argued, that he is imitating the manner of the Iliad.

\section{Conclusions}

Productive comparisons should take into full account the semantic significance of the traditional craft of early Greek epic poetry. We have sought to strengthen the case that the poet of the Odyssey imitated the Iliad when devising the dialogue between Zeus and Poseidon. Previous attempts, which relied on compositional details of a relatively small scale, have proved unconvincing under a close consideration of the background of conventions emerging from the rest of the epic corpus. If the relevant techniques are downplayed, one risks losing sight of the infrastructural specificities of this poetry. This hampers our appreciation of the poets' methods and intentions, and of their interactions with the audience - especially if they were engaging in imitation and emulation. In our example, the compositional differences between the two scenes are not to be seen as by-products of an imitation which left clumsy signs for us to trace. Rather, it is by virtue of such inherited devices that epic poets could construe appropriate characterisations and, in our Odyssey scene, activate an imitation which does not amount to an allusion.

This test-case, thus, confirms that the traditional background should not be held to preclude per se the possibility of disclosing imitation in early Greek epic. But it also clarifies that, when assessing Homeric intertextuality, we must ask how such a background shaped the possibilities of imitation in the light of what a traditionally-trained audience might have expected.

The ancient commentators perceived that through the destructions discussed by Poseidon and Zeus Homer was displaying his own power to create and annihilate. We have noticed that both scenes play a comparable role in reflecting on the destruction of the crucial poetic object in the structure of both poems (the Achaean wall, Scherie). If it is accepted that the poet of the Odyssey did engage in a complex structural emulation of the Iliad, it could be maintained that his competitive awareness was in part responsible for that most ambiguous and powerful non finito, the disappearance of Phaeacia.

\section{References}

andersen, $\varnothing$. (1990) 'The Making of the Past in the Iliad', Harvard Studies in Classical Philology $93,25-45$.

ANDERSEn, Ø. and HAUG, D. (eds) (2012) Relative Chronology in Early Greek Epic (Cambridge). BAKKER, E. J. (2013) The Meaning of Meat and the Structure of the Odyssey (Cambridge).

Ballesteros petrella, B. (2017) Divine Assemblies in early Greek and Mesopotamian Narrative Poetry. D.Phil. thesis (Oxford).

Our case shows that imitation is not incompatible with the 'rhetoric of traditionality': it is conveyed and shaped by it. 
BARKeR, E. and CHRISTENSEN, J. (2014) 'Even Heracles had to die: Homeric «heroism», mortality and the epic tradition', in TSAGALIS, C. (ed) 249-77.

вassett, S. E. (1933) 'The fate of the Phaeacians ( $v$ 125-87; cf. $\theta$ 565-71)', Classical Philology 28, $305-7$.

BLÖSSNER, N. (1992) Review of K. USENER 1990, Gnomon 54, 385-90.

BONNET, C. (2017) 'Les dieux en assemblée', in PIRONTI, G. and BONNET, c. (eds) (2017) Les dieux

d'Homère. Polythéisme et poésie en Grèce ancienne (Liège) 87-112.

BOWIE, A. M. (2013) Odyssey. Books XIII-XIV (Cambridge).

воyD, т. W. (1995) 'A Poet on the Achaean Wall', Oral Tradition 10, 181-206.

Bozzone, C. (2014) Constructions: A New Approach to Formularity, Discourse, and Syntax in Homer.

$\mathrm{PhD}$ diss. UCLA (Los Angeles).

BURgess, J. (2006) 'Neoanalysis, Orality, and Intertextuality: An Examination of Homeric Motif

Transference', Oral Tradition 21, 148-89.

BURgess, J. (2009) The Death and Afterlife of Achilles (Baltimore).

BURGESS, J. (2012) 'Intertextuality without text in Early Greek Epic', in ANDERSEN, Ø. and HAUG,

D. (eds) $168-83$.

BURGeSS, J. (2017) 'The Tale of Meleager in the Iliad', Oral Tradition 31, 51-76.

Chantraine, P. (1999) Dictionnaire étymologique de la langue grecque: histoire des mots. Avec un

Supplément. Sous la direction de A. Blanc, C. de Lamberterie, J.-L. Perpillou (Paris).

Clauss, J. J., Cuypers, M. and Kahane, A. (eds) (2016) The Gods of Greek Hexameter Poetry

(Stuttgart).

CLAY, J. S. (1983) The Wrath of Athena. Gods and Men in the Odyssey (Princeton).

CLAY, J. s. (2006) The Politics of Olympus. Form and Meaning in the major Homeric Hymns (London).

CLAY, J. s. (2011) Homer's Trojan Theatre: Space, Vision and Memory in the Iliad (Cambridge).

CURrie, B. (2006) 'Homer and the Early Epic Tradition', in ClARKe, M., CURRIE, B. and LYNe, R. (eds.) Epic Interactions. Perspectives on Homer, Virgil, and the Epic Tradition presented to Jasper Griffin by Former Pupils (Oxford) 1-46.

CURrie, B. (2012) 'The Iliad, Gilgamesh, and Neoanalysis', in MONTANARI, F., RENGAkos, A. and TSAGALIS, C. (eds) 543-80.

CURrie, B. (2016) Homer's Allusive Art (Oxford).

DANEK, G. (1992) Review of K. USENER 1990, Wiener Studien 105, 263-5.

DANEK, G. (1996) 'Intertextualität der Odyssee, Intertextualität der Ilias', Wiener Humanistische Blätter 38, 22-36.

DANEK, G. (1998) Epos und Zitat. Studien zu den Quellen der Odyssee (Wien).

DANeK, G. (2010) 'The Homeric Epics as Palimpsests', in AleXANDer, P., LANGE, A. and PILL-

INGER, R. (eds) In the Second Degree. Paratextual Literature in Ancient Near Eastern and Ancient

Mediterranean Culture and Its Reflections in Medieval Literature (Leiden) 123-36.

DANEK, G. (2016) 'Modes of Intertextuality in Homer and Bosnian Epic', in GALLO, F. (ed) Omero: Quaestiones Disputatae (Milano) 123-45.

DAVIES, M. (1986) 'Nestor's Advice in Iliad 7', Eranos 84, 69-76.

Di benedetto, v. (1998) Nel Laboratorio di Omero (Torino).

Di benedetto, v. (2001) 'Reuses of Iliadic Patterns in the Odyssey', Rivista di Cultura Classica e Medioevale 43, 7-14.

Dowden, K. (1996) 'Homer's sense of text: Homeric 'text', Cyclic 'text', Journal of Hellenic Studies $116,47-61$.

DOWDEN, K. (2004) 'The epic tradition in Greece', in FOWLER, R. L. (ed) The Cambridge Companion to Homer (Cambridge) 188-205.

EDWARDS, M. W. (1986) 'Homer and Oral Tradition: The Formula, Part I', Oral Tradition 1, 171-230. ERBSE, H. (1972) Beiträge zur Verständnis der Odyssee (Berlin).

FINGLASs, P. (2006) 'The ending of Iliad 7', Philologus 150, 187-97.

$$
\begin{aligned}
& \text { This material is under copyright. Any use outside of the narrow boundaries } \\
& \text { of copyright law is illegal and may be prosecuted. } \\
& \text { This applies in particular to copies, translations, microfilming } \\
& \text { as well as storage and processing in electronic systems. } \\
& \text { c Franz Bueiner SeeliagerStrteglatg2020 }
\end{aligned}
$$


Finkelberg, M. (2004) 'Oral Theory and the Limits of Formulaic Diction', Oral Tradition 19, $236-52$.

finkelberg, M. (2011) 'Homer and His Peers. Neoanalysis, Oral Theory, and the Status of Homer', Trends in Classics 3, 197-208.

Friedrich, R. (2011) 'Formelsprache', in Rengakos, A. and zimmermanN, B. (eds) Homer-Handbuch (Stuttgart) 41-63.

GARvie, A. F. (1994) Homer. Odyssey Books VI-VIII (Cambridge).

Genette, G. (1982) Palimpsestes: La Littérature au second degré (Paris).

GRIfFIN, G. (1991) Review of K. USENER 1990, Classical Review 41, 288-91.

hainsworth, J. B. (1993) The Iliad. A Commentary, Vol. 3: Books 9-12 (Cambridge).

HAUBOLD, J. (2014) 'Kulturkontakt aus der Sicht des Homerlesers', in ROLLINGER, R. and SCHNEGG, K. (eds) Kulturkontakte in antiken Welten: vom Denkmodell zum Fallbeispiel (Leuven) $325-42$.

HeUbeCK, A. (1954) Der Odyssee Dichter und die Ilias (Erlangen).

HOEKSTRA, A. (1988) = HEUBECK, A. and HOEKSTRA, A. (1988) A Commentary on Homer's Odyssey. Volume II: Books IX-XVI (Oxford).

Jасову, F. (1933) 'Die geistige Physiognomie der Odyssee', Die Antike 9, 159-94, repr. in: JAсову, F. (1961) Kleine Philologische Schriften vol. i (Berlin) 107-38.

JONES, B. (2012) 'Relative Chronology and an 'Aeolic' phase of epic', in ANDERSEN, Ø. and HAUG, D. (eds) 44-64.

DE JONG, I. J. F. (1987) Narrators and Focalizers: The Presentation of the Story in the Iliad (Amsterdam), 2nd ed. 2004 (London).

DE JONG, I. J. F. (2001) A Narratological Commentary on the Odyssey (Cambridge).

DE JONG, I. J. F. (2006) 'The Homeric narrator and his own kleos', Mnemosyne 59, 188-207.

Kelly, A. (2006) 'Neoanalysis and the Nestorbedrängnis: A Test-Case', Hermes 134, 1-25.

Kelly, A. (2007) A Referential Commentary and Lexicon to Homer, Iliad VIII (Oxford).

Kelly, A. (2008) 'The ending of Iliad 7: a response', Philologus 152, 5-17.

KELly, A. (2012) 'The Mourning of Thetis: “Allusion”' and the Future of the Iliad', in MONTANARI, F., RENGAKOS, A. and TSAGALIS, C. (eds) 221-65.

Kelly, A. (2015) Review of E. J. BAKker (2013), Mnemosyne 68, 677-81.

KELLY, A. (2018) 'Homer's rivals? Internal narrators in the Iliad', in READY, J. L. and TSAGALIS, C.

(eds) Homer in Performance. Rhapsodes, Narrators and Characters (Austin) 351-77.

KIRK, G. s. (1990) The Iliad. A Commentary. Vol 2: Books 5-8 (Cambridge).

KLOSS, G. (2001) 'Thukydides 1,11,1 und die Schiffsmauer in der Ilias', Rheinisches Museum für Philologie 144, 325-32.

KorenJAK, M. (1998) 'Homerische Intertextualität ohne Formeln? Zwei phorminxspielende

Helden in Ilias und Odyssee', Materiali e Discussioni per l'analisi dei testi Classici 40, 133-43.

KRISCHER, T. (1985) 'Phäaken und Odyssee', Hermes 113, 9-21.

KRISTEVA, J. (1969) Séméiôtiké: recherches pour une sémanalyse (Paris).

KullmanN, w. (1991) 'Ergebnisse der motivgeschichtlichen Forschung zu Homer (Neoanalyse)',

in LATACZ, J. (ed) Zweihundert Jahre Homer-Forschung. Rückblick und Ausblick (Stuttgart) 425-

55 .

maitland, J. (1999) 'Poseidon, Walls, and Narrative Complexity in the Homeric Iliad', Classical

Quarterly 49, 1-13.

MARKS, J. (2008) Zeus in the Odyssey (Washington, D. C.).

marks, J. (2016) 'Herding Cats: Zeus, the Other Gods and the Plot of the Iliad', in Clauss, J. J., CUYPERS, M. and KAHANe, A. (eds) 60-75.

martin, R. P. (2016) 'Poseidon in the Odyssey', in Clauss, J. J., Cuypers, M. and Kahane, A.

(eds) 76-94.

MONRO, D. B. (1901) Homer's Odyssey: Books XIII-XXIV (Oxford). 
montanari, F., Rengakos, A. and tSagalis, c. (eds) (2012) Homeric Contexts: Neoanalysis and

The Interpretation of Oral-Poetry (Berlin).

NAGY, G. (1979) The Best of the Achaeans. Concepts of Hero in Archaic Greek poetry (Baltimore).

NIESE, B. (1882) Die Entwicklung der homerische Poesie (Berlin).

PACHE, C. O. (2014) 'Theban Walls in Homeric Epic', in TSAGAlis, C. (ed) 278-96.

PAGE, D. L. (1955) The Homeric Odyssey (Oxford).

PARKER, R. (2011) On Greek Religion (Ithaca).

PFEIFFER, R. (1968) History of Classical Scholarship: From the Beginnings to the End of the Hellenistic Age (Oxford).

pontAnI, F. (2007) Scholia Graeca in Odysseam. I. Scholia ad libros $\alpha-\beta$ (Roma).

pONTANI, F. (2010) Scholia Graeca in Odysseam. II. Scholia ad libros $\gamma-\delta$ (Roma).

PORTER, J. (2011) 'Making and Unmaking: The Achaean Wall and the Limits of Fictionality in Ho-

meric Criticism', Transactions of the American Philological Association 141, 1-36.

PUCCI, P. (1987) Odysseus Polutropos. Intertextual readings in the Odyssey and the Iliad (Ithaca).

REINHARDT, K. (1961) Die Ilias und ihr Dichter (Göttingen).

Rengakos, A. (2015) 'Aethiopis', in FAntuzzi, M. and tSAGAlis, c. (eds) The Epic Cycle and Its

Ancient Reception. A Companion (Cambridge) 306-17.

romano martín, s. (2009) El tópico greco-latino del concilio de los dioses (Hildesheim).

RÖMER, A. (1924) Die Homerexegese Aristarchs in ihren Grundzügen (Paderborn).

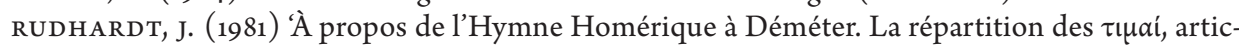

ulation centrale des systèmes mythiques grecs. Le rapt de Perséphone considéré comme un ép-

isode de cette répartition', in J. R., Du mythe, de la religion grecque et de la compréhension d'autrui

(Genève) 227-44.

RUTHERFORD, R. B. (1993) 'From the Iliad to the Odyssey', Bulletin of the Institute of Classical Studies

$38,37-54$.

SAÏD, s. (2011) Homer and the Odyssey (Oxford).

SAmmons, в. (2017) Device and Composition in the Greek Epic Cycle (Oxford).

SChein, S. L. (1999) 'Homeric Intertextuality: Two Examples', in KAzAzIS, J., Rengakos, A.

(eds) Euphrosyne: Studies in Ancient Epic and Its Legacy in Honour of Dimitris N. Maronitis (Stuttgart) 349-56.

SCODEL, R. 1982. 'The Achaean Wall and the Myth of Destruction', Harvard Studies in Classical Philology 86, 33-50.

SCODEL, R. (1997) 'Pseudo-Intimacy and the Prior Knowledge of the Homeric Audience', Arethusa 30, 201-19.

SCODEL, R. (1998) 'Bardic Performance and Oral Tradition in Homer', American Journal of Philol-

ogy $119,171-94$.

SCODEL, R. (2002) Listening to Homer. Tradition, Narrative and Audience (Ann Arbor).

scully, s. (1984) 'The Language of Achilleus: The OX $\Theta H \Sigma A \Sigma$ Formulas', Transactions of the

American Philological Association 114, 11-24.

SiтtL, к. (1882) Die Wiederholungen in der Odyssee (München).

SLATER, W. J. (1986) Aristophanis Byzantii Fragmenta post A. Nauck collegit, testimoniis ornavit, brevi commentario instruxit William J. Slater (Berlin).

TSAGALIS, C. (2008) The Oral Palimpsest: Exploring Intertextuality in the Homeric Epics (Washington, D. C.).

TSAGALIS, C. (2011) 'Towards an Oral, Intertextual Neoanalysis', Trends in Classics 3, 209-44.

tSAGalis, C. (2016) 'The Gods in Cyclic Epic', in Clauss, J. J., CUypers, M. and Kahane, A.

(eds) $95-117$.

TSAGAlIS, C. (ed) (2014) Theban Resonances in Homeric Epic (Berlin).

USENER, K. (1990) Beobachtungen zur Verhältnis der Odyssee zur Ilias (Tübingen).

WeSt, M. L. (1969) 'The Achaean Wall', Classical Review 19, 256-60. 
West, M. L. (2003) 'Iliad and Aethiopis', Classical Quarterly 53, 1-14.

WEST, M. L. (2012) 'Towards a chronology of early Greek epic', in ANDERSEN, Ø. and HAUG, D. (eds) 224-41.

West, M. L. (2013) The Epic Cycle. A Commentary on the Lost Troy Epics (Oxford).

WEST, M. L. (2014) The Making of the Odyssey (Oxford).

WeSt, S. R. (1981) = HeUbeCK, A., WeSt, s. R., and Previtera, G. A. (1981) Omero, Odissea. Volume I (Libri I-IV) Introduzione generale di Alfred Heubeck e Stephanie West. Testo e commento a cura di Stephanie West. Traduzione di G. Aurelio Previtera (Milano).

WEST, S. R. (1988) = HEUBECK, A., WEST, S. R., and HAINSWORTH, J. B. (1988) A Commentary on Homer's Odyssey. Volume I, Books I-VIII (Oxford).

WILlCock, M. (1997) 'Neoanalysis', in MORRIS, I. and POWell, в. в. (eds) A New Companion to Homer (Leiden) 174-89.

DR BERNARDO BALLESTEROS

München 